\title{
DAMPAK PERTUMBUHAN PENDUDUK TERHADAP DAYA DUKUNG LAHAN PERTANIAN DI DESA SAMBANGAN
}

\author{
I Made Yogi Jayadi, Putu Indra Christiawan, I Made Sarmita \\ Jurusan Pendidikan Geografi \\ Universitas Pendidikan Ganesha \\ Singaraja, Indonesia
}

e-mail: \{jayadi.yogi@gmail.com, putu.ic87@gmail.com, madesarmita@ymail.com\}

\begin{abstract}
ABSTRAK
Penelitian ini bertujuan (1) untuk mengetahui pertumbuhan penduduk Desa Sambangan dari tahun 2012 hingga tahun 2016, (2) untuk mengetahui daya dukung lahan pertanian Desa Sambangan dari tahun 2012 hingga tahun 2016, dan (3) untuk mengetahui dampak pertumbuhan penduduk terhadap lahan pertanian di Desa Sambangan dari tahun 2012 hingga tahun 2016. Metode pengumpulan data yang digunakan adalah metode pencatatan dokumen. Data dianalisis secara deskriptif kualitatif dan deskriptif kuantitatif. Hasil penelitian ini menunjukkan bahwa (1) Pertumbuhan penduduk Desa Sambangan mengalami peningkatan setiap tahun. Berdasarkan hasil analisis dengan menggunakan persamaan eksponensial diperoleh rata-rata laju pertumbuhan penduduk di Desa Sambangan sebesar $1,41 \%$ per tahun dalam periode tahun 2012-2016. (2) Dalam periode tahun 2012-2016, luas lahan pertanian mengalami penurunan akibat adanya alih fungsi lahan pertanian ke non pertanian, namun nilai daya dukung lahan pertanian Desa Sambangan masih memenuhi standar evaluasi, yaitu $\alpha>1$. Hal ini menunjukan bahwa daya dukung lahan pertanian di Desa Sambangan masih mampu berswasembada pangan dan mampu memberikan kehidupan yang layak bagi penduduknya. (3) Laju pertumbuhan penduduk Desa Sambangan memiliki dampak negatif terhadap nilai daya dukung lahan pertanian di wilayah tersebut. Hasil uji korelasi pearson product moment diperoleh koefisien korelasi besar koefisien korelasi nilai $r_{\text {hitung }}>r_{\text {tabel }}$ yaitu $0,949>0,878$. Hasil uji regresi linier sederhana diperoleh persamaan $Y=14,297-2,319 X$.
\end{abstract}

Kata-kata kunci: Penduduk, Pertumbuhan Penduduk, Lahan Pertanian, dan Daya Dukung Lahan

\begin{abstract}
This study aims to (1) to find out the growth of Sambangan Village residents from 2012 to 2016, (2) to know the supporting capacity of Sambangan Village farming land from 2012 to 2016, and (3) to know the impact of population growth on agricultural land in Sambangan Village from 2012 until 2016. Data collection method used is document recording method. Data were analyzed descriptively qualitative and descriptive quantitative. The results of this research are (1) The growth of Sambangan Village population has increased every year. Based on the results of analysis using exponential equation obtained the average rate of population growth in Sambangan Village amounted to $1,41 \%$ in the period 2012-2016. (2) In the period of 2012-2016, the area of agricultural land has decreased due to the conversion of agricultural land to non-agricultural land. The supporting capacity of farming land of Sambangan Village from 2012-2016 meet the evaluation standard, that is. This shows that the carrying capacity of agricultural land in Sambangan village is capable of food self-sufficiency and able to provide a decent living for its inhabitants. (3) The population growth rate of Sambangan Village has a negative impact on the carrying capacity of agricultural land in the area. Correlation test results pearson product moment obtained large correlation coefficient value correlation coefficient $r_{\text {hitung }}>r_{\text {tabel }}$ that is $0,949>0,878$. The results of simple linear regression test obtained equation $Y=14,297-2,319 X$.
\end{abstract}

Key Words: Population, Population Growth, Agricultural Land, and Land Supporting Capacity 


\section{A. PENDAHULUAN}

Penduduk adalah orang-orang yang berada di dalam suatu wilayah yang terikat oleh aturan-aturan yang berlaku dan saling berinteraksi satu sama lain secara terus menerus. Jumlah penduduk senantiasa berubah dari waktu ke waktu. Jumlah penduduk disuatu daerah selalu mengalami peningkatan ataupun penurunan setiap tahun. Pertambahan penduduk adalah perubahan populasi sewaktu-waktu dan dapat dihitung sebagai perubahan dalam jumlah individu dalam sebuah populasi menggunakan per waktu unit unyuk pengukuran. Ketika pertumbuhan penduduk dapat melewati kapasitas muat suatu wilayah atau lingkungan hasilnya berakhir dengan kelebihan penduduk. Pertumbuhan penduduk disebabkan oleh beberapa faktor, yaitu kelahiran, kematian, dan perpindahan penduduk. Berdasarkan data dari Badan Pusat Statistik (BPS), Bali merupakan salah satu provinsi di Indonesia yang memiliki luas wilayah 5.636,66 km2 dengan jumlah penduduk yang tercatat tahun 2016 sebanyak 4.200.000 jiwa dengan kepadatan penduduk sebesar 745 jiwa/km2. Jumlah penduduk di Bali meningkat 1,14\% dari tahun sebelumnya (BPS Provinsi Bali, 2017).

Tingginya laju pertumbuhan penduduk disuatu daerah diikuti pula dengan laju pertumbuhan permukiman. Jumlah pertumbuhan permukiman yang terus menerus meningkat sehingga akan menyebabkan tingginya tekanan terhadap daya dukung lahan. Pertumbuhan jumlah penduduk yang terus meningkat menyebabkan terjadinya perkembangan permukiman yang diikuti dengan pengelolaan yang tidak terkontrol. Adanya pertumbuhan jumlah penduduk membuat lahan memberikan arti penting bagi keberlangsungan hidup manusia.

Bali memiliki luas lahan pertanian yang tetap dengan pertumbuhan penduduknya yang meningkat. Seiring meningkatnya jumlah penduduk maka jumlah permukiman juga semakin meningkat. Pertumbuhan penduduk mengakibatkan permasalahan pemanfaatan lahan menjadi lebih kompleks dan sangat kompetitif (Suputra, 2012: 66). Hal ini akan membuat terjadinya alih fungsi lahan pertanian ke non pertanian. Ketersediaan lahan pertanian akan menjadi semakin berkurang.

Alih fungsi (konversi) lahan merupakan proses perubahan penggunaan fungsi sebagian atau seluruh kawasan lahan dari fungsi semula menjadi fungsi yang lainnya. Alih fungsi lahan ini terjadi secara dinamis dan perubahannya cenderung searah dengan meningkatnya jumlah populasi penduduk. Jumlah penduduk yang terus meningkat dan aktifitas pembangunan yang dilakukan telah banyak menyita fungsi lahan pertanian. Laju konversi lahan sawah untuk kegiatan di luar bidang pertanian sudah sangat mengkhawatirkan, bahkan bisa mengancam produksi pangan dalam negeri (Syaiffudin, Hamrie, \& Dahlan, 2016). Aktifitas pembangunan fisik yang sangat cepat namun pada umumnya tidak disertai daya dukung (carrying capasity) lahan yang memadai menyebabkan pemanfaatan lahan yang tidak semestinya. Akibat dari keadaan ini menyebabkan kemampuan lahan pertanian untuk memenuhi kebutuhan makanan bagi penduduk semakin berkurang. Hal itu berarti bahwa daya dukung lahan pertanian akan semakin kecil. Konversi lahan pertanian akan menjadi ancaman serius bagi ketahanan pangan di Bali karena lahan pertanian yang telah dikonversi sangat kecil peluangnya untuk diubah kembali menjadi lahan pertanian.

Notohadiprawiro (dalam Ariani \& Harini, 2012:32) mengemukakan bahwa kemampuan lahan menyiratkan daya dukung lahan. Kemampuan lahan adalah mutu lahan yang dinilai secara menyeluruh dengan pengertian merupakan suatu pengenal majemuk lahan dan nilai kemampuan lahan berbeda untuk penggunaan yang berbeda. Dalam kaitannya dalam pemenuhan kebutuhan manusia, maka kemampuan lahan terjabarkan menjadi pengertian daya dukung lahan.

Imbangan tingkat pemanfaatan lahan dengan daya dukung lahan menjadi 
e-journal Universitas Pendidikan Ganesha Jurusan Pendidikan Geografi (Vol 8 Tahun 2018)

ukuran kelayakan penggunaan lahan. Sebaliknya jika pemakaian lahan telah melampaui kemampuan daya dukung lahan, maka pemanfaatan lahan tidak dipakai secara efektif. Dari uraian tadi maka secara jelas dapat dikatakan bahwa daya dukung lahan adalah kemampuan bahan pada suatu satuan lahan untuk mendukung kebutuhan-kebutuhan manusia dalam bentuk penggunaan lahan, yang pada akhirnya tujuannya adalah untuk memenuhi kebutuhan manusia terutama bahan makanan.

Astawa dan Sarmita (2016:225) mengungkapkan peningkatan jumlah penduduk perlu mendapat perhatian mengingat dampaknya sangat luas. Jumlah penduduk yang meningkat berarti pemenuhan kebutuhan hidup juga meningkat seperti sandang, pangan, papan, energi, kesempatan kerja, kesehatan pendidikan, dan hak dasar lainnya. Kepadatan penduduk disetiap daerah memiliki perbedaan hal tersebut disebabkan oleh persebaran sumber daya alam tidak merata.

Wilayah Bali yang memiliki luas terbesar dibandingkan dengan yang lainnya adalah Kabupaten Buleleng. Luas wilayah kabupaten Buleleng mencapai $1.365,88 \mathrm{~km} 2$ dengan jumlah penduduk sebanyak 650.100 jiwa pada tahun 2016 (BPS Provinsi Bali, 2017). Jumlah penduduk di kabupaten Buleleng mengalami peningkatan setiap tahunnya. Salah satu daerah yang mengalami peningkatan jumlah penduduk yang cukup pesat adalah Desa Sambangan.

Desa sambangan terletak dipinggiran kota Singaraja. Berdasarkan data Badan Pusat Statistik Kabupaten Buleleng (2016), Desa Sambangan memiliki luas wilayah sebesar 7,67 km2 dengan jumlah penduduk yang meningkat setiap tahun. Adapun data jumlah penduduk Desa Sambangan disajikan pada Tabel 1.

Tabel 1.Data Jumlah Penduduk Desa Sambangan

\begin{tabular}{|l|l|l|}
\hline Tahun & $\begin{array}{c}\text { Jumlah penduduk } \\
\text { (jiwa) }\end{array}$ & $r(\%)$ \\
\hline 2012 & 5869 & 0,97 \\
\hline 2013 & 5945 & 1,27 \\
\hline 2014 & 6023 & 1,29 \\
\hline
\end{tabular}

\begin{tabular}{|l|l|l|}
\hline 2015 & 6148 & 2,03 \\
\hline 2016 & 6300 & 2,41 \\
\hline
\end{tabular}

(Sumber: BPS Kabupaten Buleleng, 2012-2016)

Berdasarkan Tabel 1 menunjukan bahwa setiap tahun jumlah penduduk di Desa Sambangan meningkat. Persediaan lahan diperkotaan untuk permukiman penduduk semakin berkurang sehingga penduduk berpindah menuju daerah yang memiliki potensi lahan yang memadai untuk permukiman. Desa Sambangan yang letaknya yang strategi dipinggiran kota membuat penduduk berpindah ke daerah tersebut. Hal ini menyebabkan meningkatnya tuntutan akan kebutuhan lahan untuk permukiman penduduk. Persedian lahan pada suatu daerah sangat terbatas dan tidak mampu mendukung kebutuhan penduduk untuk permukiman.

Desa Sambangan memiliki lahan pertanian yang cukup luas dibandingkan beberapa desa lainnya yang terdapat di Kecamatan Sukasada. Namun, seiring meningkatnya jumlah penduduk akan menyebabkan terjadinya alih fungsi lahan pertanian ke non pertanian, misalnya menjadi sebuah permukiman, perkantoran, dan lain sebagainya. Luas lahan pertanian di Desa Sambangan setiap tahun semakin berkurang. Hal ini ditunjukan pada Tabel 2 yang disajikan sebagai berikut.

Tabel 2. Luas Lahan Pertanian Desa Sambangan

\begin{tabular}{|l|l|l|}
\hline Tahun & Luas (ha) & $r(\%)$ \\
\hline 2013 & 257 & $-1,94$ \\
\hline 2014 & 248 & $-3,63$ \\
\hline 2015 & 237 & $-4,64$ \\
\hline 2016 & 222 & $-6,75$ \\
\hline
\end{tabular}

(Sumber: BPS Kabupaten Buleleng, 2012-2016)

Berdasarkan Tabel 2 menunjukan bahwa luas lahan pertanian Desa Sambangan mengalami pengurangan setiap tahun, terhitung dari tahun 2012 hingga tahun 2016. Seiring terjadinya pengurangan terhadap luas lahan pertanian, jumlah penduduk Desa Sambangan justru mengalami peningkatan setiap tahun. Mantra (1986: 58), mengatakan bahwa penurunan daya dukung lahan dipengaruhi oleh jumlah 
e-journal Universitas Pendidikan Ganesha Jurusan Pendidikan Geografi (Vol 8 Tahun 2018)

penduduk yang terus meningkat, luas lahan yang semakin berkurang, persentase jumlah petani dan luas lahan yang diperlukan untuk hidup layak. Semakin tinggi jumlah penduduk akan menyebabkan kebutuhan lahan untuk permukiman juga semakin tinggi, hal ini akan menyebabkan terjadinya penurunan daya dukung lahan (Ariani \& Harini, 2012:30). Perubahan fungsi lahan pertanian di Desa Sambangan semakin mengurangi kesempatan usaha yang pada akhirnya mengancam pendapatan petani.

Alih fungsi lahan mengakibatkan luas lahan sawah semakin menyempit. Perubahan fungsi lahan pertanian ke nonpertanian sangat signifikan, sehingga proses alih fungsi tersebut sangat membawa dampak yang cukup besar bagi masyarakat petani. Hal ini akan mengakibatkan terjadinya proses transformasi spasial di Desa Sambangan berupa proses densifikasi permukiman dan transformasi sosial ekonomi sebagai dampak lebih lanjut. Atas dasar fenomena di atas, maka dipandang penting meneliti tentang "Dampak Pertumbuhan Penduduk terhadap Daya Dukung Lahan Pertanian di Desa Sambangan".

Tujuan dari penelitian ini adalah menganalisis pertumbuhan penduduk di Desa Sambangan, menganalisis daya dukung lahan pertanian di Desa Sambangan, menganalisis dampak pertumbuhan penduduk terhadap daya dukung lahan pertanian di Desa Sambangan.

\section{B. METODE PENELITIAN}

Rancangan penelitian merupakan kerangka umum untuk melakukan suatu penelitian. Penelitian ini menggunakan tipe penelitian deskriptif. Dalam penelitian ini yang dideskripsikan adalah pertumbuhan penduduk di Desa Sambangan dan daya dukung lahan pertanian di Desa Sambangan.

Lokasi dalam penelitian ini adalah Desa Sambangan yang merupakan salah satu desa yang terdapat di kecamatan Sukasada yang terletak dipinggiran kota. Berdasarkan data dari Badan Pusat Statistik Kabupaten Buleleng, jumlah penduduk di Desa Sambangan dari tahun
2012 hingga 2016 mengalami peningkatan secara signifikan. Jumlah penduduk di Desa Sambangan tahun 2012 sebanyak 5869 jiwa dan tahun 2016 mencapai 6.300 jiwa. Peningkatan jumlah penduduk di Desa Sambangan menyebabkan terjadinya banyak alih fungsi lahan pertanian ke non pertanian, misalnya menjadi permukiman penduduk, kantor, dan lain sebagainya. Hal ini mengakibatkan kemampuan lahan pertanian dalam mendukung kehidupan menjadi berkurang..

Objek penelitian ini adalah dampak pertumbuhan penduduk terhadap daya dukung lahan pertanian di Desa Sambangan, yang dikaji dari sudut pandang geografi penduduk. Berdasarkan hal tersebut, subjek dalam penelitian ini adalah penduduk secara agregat setiap banjar dinas di Desa sambangan dan lahan pertanian di Desa Sambangan. Populasi dalam penelitian ini adalah subjek itu sendiri. Penelitian ini tidak menggunakan sampel, seluruh populasi digunakan untuk diteliti secara agregat atau disebut dengan studi populasi.

Agar tidak menyimpang dari tujuan penelitian maka variabel-variabel dalam penelitian perlu di definisikan secara operasional. Tujuan dari pendefinisian variabel secara operasional yaitu memberikan definisi pada variabel atau istilah yang ada dalam topik atau judul penelitian agar tidak salah ditafsirkan oleh pembaca, sekaligus membatasi ruang lingkup penelitian. Variabel penelitian yang akan dioperasionalkan di lapangan yang dipandang perlu untuk didefinisikan adalah sebagai berikut: 1) Pertumbuhan penduduk 2) Daya dukung lahan pertanian. Sumber data yang digunakan dalam penelitian yaitu data sekunder.

Metode analisis yang digunakan adalah metode pencatatan dokumen. Adapun pengolahan data yang dilakukan berdasarkan masing-masing rumusan masalah

1. Laju pertumbuhan penduduk Desa Sambangan dalam jangka waktu 5 tahun terakhir dihitung secara eksponensial, dengan formulasi :

$$
P_{t}=P_{0} \cdot e^{r n}
$$


2. Daya dukung lahan pertanian Desa Sambangan dihitung dengan formulasi sebagai berikut.

$$
\alpha=\frac{X}{K}
$$

3. Dampak Pertumbuhan penduduk terhadap daya dukung lahan pertanian Menggunakan regresi linier sederhana dan analisis korelasi pearson product moment sedangkan untuk menguji adanya hubungan antara pertumbuhan penduduk dengan daya dukung lahan pertanian digunakan analisis korelasi pearson product moment.

\section{HASIL DAN PEMBAHASAN}

\section{Pertumbuhan Penduduk}

Perkembangan jumlah penduduk Desa Sambangan dari tahun 2012 hingga tahun 2016 terlihat semakin mengalami pertambahan yang cukup tinggi.Pertumbuhan penduduk Desa Sambangan dari tahun 2012-2016 disajikan pada Tabel 3.

Tabel 3. Pertumbuhan Penduduk Desa Sambangan

\begin{tabular}{|c|c|c|c|}
\hline \multirow[b]{2}{*}{$\begin{array}{c}\text { Tahu } \\
\mathbf{n}\end{array}$} & \multirow[b]{2}{*}{$\begin{array}{c}\text { Jumlah } \\
\text { pendudu } \\
\text { k (jiwa) }\end{array}$} & \multicolumn{2}{|c|}{ Pertumbuhan } \\
\hline & & $\begin{array}{c}\text { Jumlah } \\
\text { pendudu } \\
\text { k (jiwa) }\end{array}$ & $r(\%)$ \\
\hline 2012 & 5869 & 57 & $\begin{array}{c}0,9 \\
7\end{array}$ \\
\hline 2013 & 5945 & 76 & $\begin{array}{c}1,2 \\
7\end{array}$ \\
\hline 2014 & 6023 & 78 & $\begin{array}{c}1,2 \\
9\end{array}$ \\
\hline 2015 & 6148 & 125 & $\begin{array}{c}2,0 \\
3\end{array}$ \\
\hline 2016 & 6300 & 152 & $\begin{array}{c}2,4 \\
1\end{array}$ \\
\hline
\end{tabular}

Tabel 3 menunjukan bahwa dari tahun 2012-2016 pertumbuhan penduduk mengalami kenaikan secara signifikan. Jika dilihat lebih jelas maka dari tahun sebelumnya hingga tahun 2012 angka pertumbuhan penduduk yang terjadi sebesar 0,97\%. Dari tahun 2012 hingga tahun 2013 angka pertumbuhan penduduk yang terjadi sebesar $1,27 \%$. Dari tahun 2013 hingga tahun 2014 pertumbuhan penduduk meningkat menjadi 1,29\%. Dari tahun 2014 hingga tahun 2015 pertumbuhan penduduk meningkat menjadi 2,03\%. Dari tahun 2015 hingga tahun 2016 pertumbuhan penduduk meningkat sebesar $2,41 \%$. Peningkatan pertumbuhan penduduk terbesar terjadi dari tahun 2015 hingga tahun 2016, yaitu sebesar $2,41 \%$ dengan jumlah penduduk yang bertambah sebanyak 152 jiwa. Peningkatan pertumbuhan penduduk disajikan dalam bentuk grafik sebagai berikut.

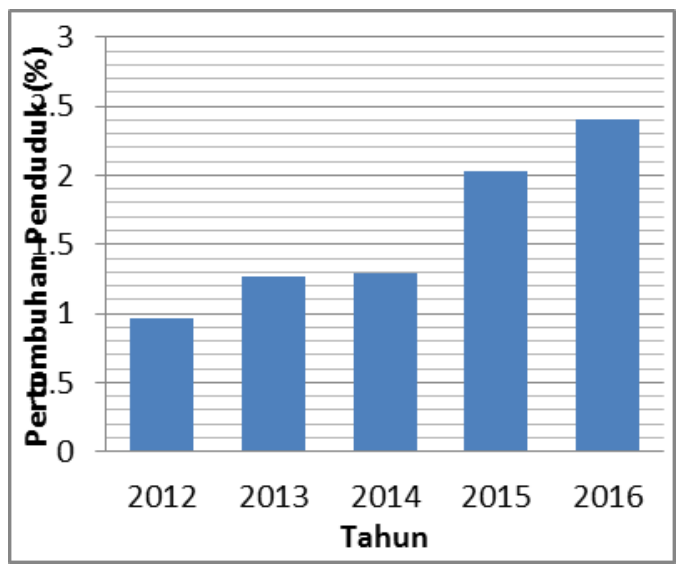

Grafik 1.Pertumbuhan Penduduk

Rata-rata laju pertumbuhan pendudukselama 5 tahun terakhir dapat dianalisis dengan menggunakan caraeksponensial. Berdasarkan data yang disajikan pada tabel 3 dapat diperoleh hasil analisis dan kajian rata-rata laju pertumbuhan penduduk 5 tahun sebagai berikut.

$$
\begin{aligned}
r & =\frac{1}{t} \ln \left(\frac{P_{t}}{P_{0}}\right) \\
& =\frac{1}{5} \ln \left(\frac{6300}{5869}\right) \\
& =\frac{1}{5} \ln (1,0734) \\
& =0,0141 \\
& =1,41 \%
\end{aligned}
$$

Berdasarkan hasil analisis dengan menggunakan cara eksponensial diperoleh hasil rata-rata laju pertumbuhan 
penduduk Desa Sambangan sebesar 1,41\% selama periode tahun $2012-2016$.

\section{Daya Dukung Lahan Pertanian}

Desa Sambangan merupakan daerah yang berada dipinggiran kota dengan lahan pertanian yang cukup luas. Desa Sambangan memiliki luas wilayah sebesar $7,67 \mathrm{~km}^{2}$ atau setara dengan 767 ha.Luas lahan pertanian Desa Sambangan tahun 2016 tercatat sebesar 222 ha. Luas lahan pertanian merupakan $28,9 \%$ dari luas wilayah Desa Sambangan.

Luas lahan pertanian Desa Sambangan mengalami pengurangan luas lahan setiap tahun.Data luas lahan pertanian Desa Sambangan dari tahun 2012-2016 disajikan pada Tabel 4.

Tabel 4. Luas Lahan Pertanian Desa Sambangan Tahun 2012-2016

\begin{tabular}{|c|c|c|}
\hline Tahun & $\begin{array}{c}\text { Luas } \\
\text { (ha) }\end{array}$ & $\mathbf{r}(\%)$ \\
\hline 2012 & 262 & $-0,52$ \\
\hline 2013 & 257 & $-1,94$ \\
\hline 2014 & 248 & $-3,63$ \\
\hline 2015 & 237 & $-4,64$ \\
\hline 2016 & 222 & $-6,75$ \\
\hline
\end{tabular}

Luas lahan pertanian Desa Sambangan dari tahun 2012-2016 juga disajikan dalam bentuk grafik sebagai berikut.

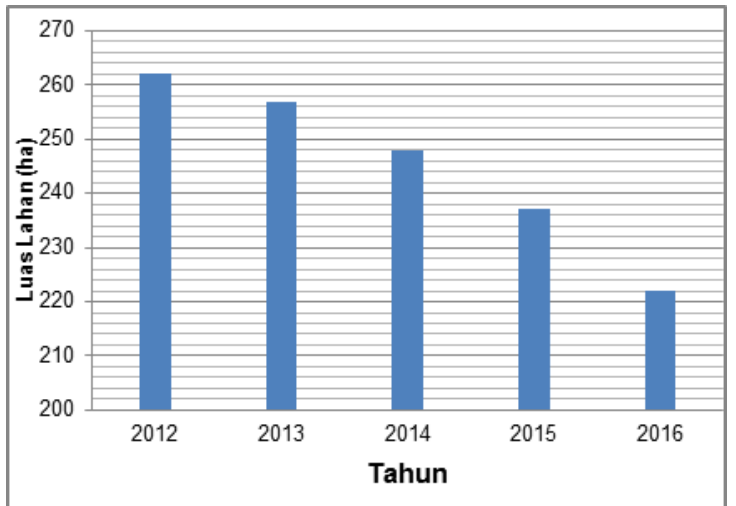

Grafik 2. Luas Lahan Pertanian Desa Sambangan

Daya dukung lahan pertanian merupakan indikator yang sederhana menunjukkan suatu wilayah dapat swasembada yang diukur dari ketersediaan bahan pangan khususnya beras. Data yang dipergunakan dalam analisis ini adalah jumlah luas lahan panen yang tersedia untuk budidaya tanaman pangan khususnya padi, jumlah penduduk pada akhir tahun, konsumsi minimal dan produksi rata-rata padi per hektar, dapat diformulasikan :

$$
\alpha=\frac{X}{K}
$$

dengan :

$$
X=\frac{\text { Jumlahpanen }(\text { ha })}{\text { Jumlah Penduduk }(\text { jiwa })}
$$

$K=\frac{\text { Kebutuhan Fisik Minimum }}{\text { ProduksiRata }- \text { rataberas } / \text { ha } / \text { tahun }}$

Untuk menghitung daya dukung lahan terlebih dahulu dicari besarnya variabel-variabel pendukungnya meliputi :

a. Perhitungan Kebutuhan Fisik Minimum Konsumsi Fisik Minimal (KFM) dihitung kebutuhan beras sebesar $151,2 \mathrm{~kg} / \mathrm{org} / \mathrm{thn}$.

b. Produksi Rata-Rata Beras dan Luas Panen

Produksi per satuan luas dan waktu (yield) dipergunakan rata-rata produksi padi per hektar, yang dikonversikan menjadi beras.Besarnya angka konversi padi ke beras menggunakan kriteria BPS yaitu sebesar $68 \%$. Berikut disajikan data luas panen dan produksi beras di Desa Sambangan 5 tahun terakhir.

Tabel 5. Luas Panen dan Produksi Beras Desa Sambangan Tahun 2012-2016

\begin{tabular}{|c|c|c|}
\hline Tahun & $\begin{array}{c}\text { Luas } \\
\text { Panen } \\
\text { (ha/tahun) }\end{array}$ & $\begin{array}{c}\text { Produksi } \\
\text { Beras } \\
\text { (ton/ha) }\end{array}$ \\
\hline 2012 & 458 & 24,3 \\
\hline 2013 & 442 & 23,3 \\
\hline 2014 & 423 & 22,7 \\
\hline 2015 & 411 & 21,9 \\
\hline 2016 & 399 & 21,0 \\
\hline
\end{tabular}

c. Jumlah Penduduk

Jumlah penduduk di suatu wilayah dihitung pada akhir tahun. Jumlah penduduk dalam suatu wilayah sangat mempengaruhi persediaan lahan 
e-journal Universitas Pendidikan Ganesha Jurusan Pendidikan Geografi (Vol 8 Tahun 2018)

di wilayah tersebut.Untuk menghitung daya dukung lahan pertanian di Desa Sambangan diperlukan data jumlah penduduk dalam jangka waktu 5 tahun terakhir.Data jumlah penduduk dari tahun 2012 hingga tahun 2016 disajikan pada Tabel 5.

Tabel 5. Jumlah Penduduk Desa Sambangan Tahun 2012-2016

\begin{tabular}{|c|c|}
\hline Tahun & $\begin{array}{c}\text { Jumlah penduduk } \\
\text { (jiwa) }\end{array}$ \\
\hline 2012 & 5869 \\
\hline 2013 & 5945 \\
\hline 2014 & 6023 \\
\hline 2015 & 6148 \\
\hline 2016 & 6300 \\
\hline
\end{tabular}

Berdasarkan

pemaparan beberapa indikator daya dukung lahan pertanian di Desa Sambangan, diperoleh hasil analisis sebagai berikut.

Tabel 6. Daya Dukung Lahan Pertanian DesaSambanganTahun 2012-2016

\begin{tabular}{|c|c|}
\hline Tahun & Daya Dukung Lahan \\
\hline 2012 & 12,54 \\
\hline 2013 & 11,45 \\
\hline 2014 & 10,54 \\
\hline 2015 & 9,68 \\
\hline 2016 & 8,79 \\
\hline
\end{tabular}

Berdasarkan Tabel 6 dapat diketahui bahwa daya dukung lahan Desa Sambangan setiap tahun mengalami pengurangan. Daya dukung lahan pertanian dari tahun 2012 sampai tahun 2013 mengalami penurunan sebesar 1,09. Dari tahun 2013 sampai tahun 2014 daya dukung lahan pertanian mengalami penurunan sebesar 0,91. Dari tahun 2014 sampai 2015 daya dukung lahan petanian mengalami penurunan sebesar 0,86. Dari tahun 2015 sampai tahun 2016 daya dukung lahan pertanian mengalami penurunan sebesar 0,92. Berdasarkan hasil analisis dapat disimpulkan bahwa penurunan drastic daya dukung lahan pertanian terjadi pada tahun 2013, yaitu sebesar 1,09.

\section{Dampak Pertumbuhan Penduduk terhadap Daya Dukung Lahan Pertanian}

Berdasarkan data sekunder yang diperoleh, adapun data pertumbuhan penduduk dan daya dukung lahan pertanian Desa Sambangan tahun 20122016 disajikan pada Tabel 7 .

Tabel 7. Pertumbuhan Penduduk dan Daya Dukung Lahan Pertanian Desa Sambangan Tahun 2012-2016

\begin{tabular}{|c|c|c|}
\hline Tahun & $\begin{array}{c}\text { Pertumbuhan } \\
\text { Penduduk }\end{array}$ & $\begin{array}{c}\text { Daya } \\
\text { Dukung } \\
\text { Lahan }\end{array}$ \\
\hline 2012 & 0,97 & 12,54 \\
\hline 2013 & 1,27 & 11,45 \\
\hline 2014 & 1,29 & 10,54 \\
\hline 2015 & 2,03 & 9,68 \\
\hline 2016 & 2,41 & 8,79 \\
\hline
\end{tabular}

Data pertumbuhan penduduk dan daya dukung lahan pertanian desa Sambangan agar terlihat lebih jelas dapat disajikan dalam bentuk grafik sebagai berikut.

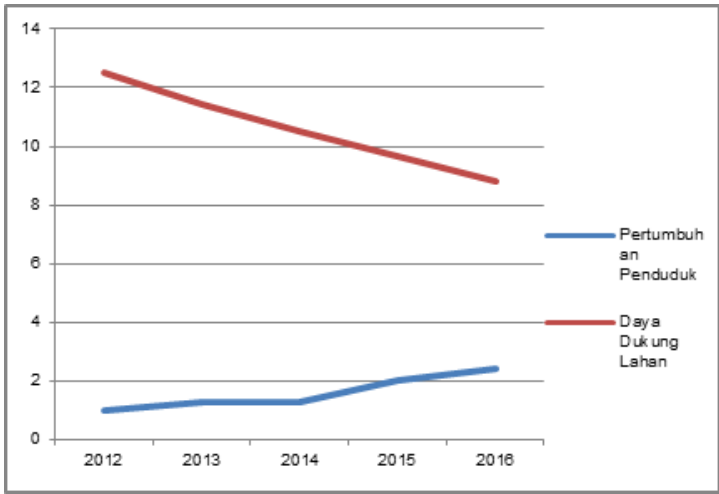

Grafik 3. Pertumbuhan Penduduk dan Daya Dukung Lahan Pertanian

Berdasarkan grafik 3 dapat diketahui pertumbuhan penduduk dan daya dukung lahan pertanian dari tahun 2012 hingga tahun 2016.Pertumbuhan penduduk semakin meningkat 5 tahun terakhir, sementara itu daya dukung lahan pertanian di Desa Sambangan semakin menurun.Untuk mengetahui besarnya pengaruh pertumbuhan penduduk terhadap daya dukung lahan pertanian dilakukan analisis data dengan regresi linier sederhana dan analisis korelasi pearson product moment. Untuk melakukan analisis tersebut, data yang diperoleh harus memenuhi uji 
e-journal Universitas Pendidikan Ganesha Jurusan Pendidikan Geografi (Vol 8 Tahun 2018)

normalitas.Berikut dipaparkan hasil analisis uji normalitas, regresi linier dan korelasi dengan menggunakan SPSS 16.0.

\section{a. Uji Normalitas Data}

Uji normalitas bertujuan untuk menguji apakah dalam model regresi, variable terikat dan variable bebas keduanya mempunyai distribusi normal atau tidak.Model regresi yang baik adalah memiliki distribusi data normal atau mendekati normal.Salah satu metode untuk mengetahui normalitas adalah dengan menggunakan metode analisis grafik, baik dengan melihat grafik secara histogram ataupun dengan melihat secara Normal Probability Plot. Normalitas data dapat dilihat dari penyebaran data (titik) pada sumbu diagonal pada grafik normal P-Plot atau dengan melihat histogram dari residualnya. Berikut disajikan output dari SPSS 16.0 yang diolah.

Tabel 8. Uji Normalitas Output SPSS 16.0

\begin{tabular}{|c|c|c|c|c|c|c|}
\hline & \multicolumn{3}{|c|}{ Kolmogoror-smimof } & \multicolumn{3}{|c|}{ Shapiro-Willk } \\
\hline & Statisistic & df & Silo. & Statisistic & df & Silo. \\
\hline Pert_Penduduk & 294 & 5 & .183 & .902 & 5 & .419 \\
\hline DD_Lahan & .135 & 5 & $.200^{\prime}$ & 990 & 5 & 979 \\
\hline
\end{tabular}

a. Lillieforos Significance Correction

*.This is a lower hound of the true significance.

Berdasarkan Tabel 8 menunjukan bahwa nilai signifikansi KolmogorovSmirnov untuk kedua variabel lebih besar dari 0,05. Data dikatakan berdistribusi normal apabila nilai sig $>0,05$. Nilai sig untuk variabel pertumbuhan penduduk sebesar 0,183 sedangkan variabel daya dukung lahan pertanian memiliki nilai sig sebesar 0,200. Hal ini menunjukan bahwa data-data yang digunakan berdistribusi Detrended Normal Q-Q Plot of DD_Lahan

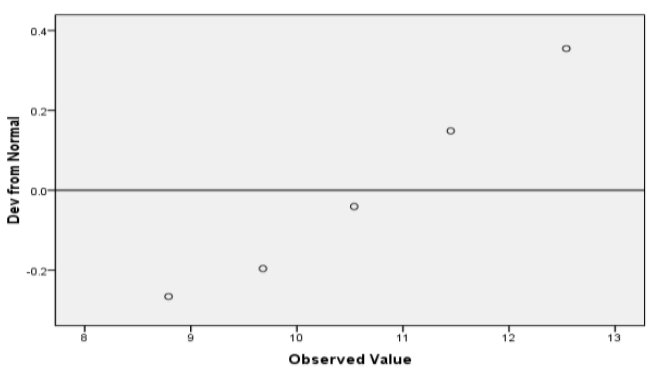

normal.

\section{Gambar 1. Grafik Uji Normalitas}

Dari gambar 1 sebagaimana terlihat dalam grafik Normal $P-P$ plot of regression Standardized Residual, terlihat bahwa titik-titik menyebar disekitar garis diagonal, serta penyebarannya mengikuti arah garis diagonal (membentuk garis lurus), maka dapat dikatakan bahwa data berdistribusi normal dan model regresi layak dipakai untuk memprediksi daya dukung lahan pertanian berdasarkan variabel bebasnya.

\section{b. Analisis Korelasi Product Moment}

Berdasarkan penelitian yang dilakukan, pada tahun 2012- 2016 pertumbuhan penduduk di Desa Sambangan mengalami pergerakan yang cukup fluktuatif. Pertumbuhan penduduk yang terus bergerak naik dikhawatirkan memiliki hubungan dengan daya dukung lahan pertanian di Desa Sambangan. Pertumbuhan penduduk yang semakin meningkat akan membutuhkan lahan untuk permukiman, sehingga akan terjadi alih fungsi lahan pertanian ke non pertanian. Berdasarkan data yang diperoleh, hasil analisis korelasi Product moment dengan menggunakan SPSS 16.0 disajikan pada Tabel 9.

Tabel 9. Hasil Korelasi Pertumbuhan Penduduk dengan Daya Dukung Lahan Pertanian Tahun 2012-2016

\begin{tabular}{|ll|r|r|}
\hline & & \multicolumn{1}{|c|}{$\begin{array}{c}\text { Pert } \\
\text { Penduduk }\end{array}$} & DD_Lahan \\
\hline Pert_Penduduk & Pearson Correlation & 1 & $-.949^{\prime}$ \\
& Sig. (2-tailed) & & .014 \\
& $\mathrm{~N}$ & 5 & 5 \\
\hline DD_Lahan & Pearson Correlation & $-.949^{\prime}$ & 1 \\
& Sig. (2-tailed) & .014 & \\
& $\mathrm{~N}$ & 5 & 5 \\
\hline
\end{tabular}

*. Correlation is significant at the 0.05 level (2-tailed).

Berdasarkan tabel 9 diperoleh koefisien korelasi antara pertumbuhan penduduk dengan daya dukung lahan pertanian Desa Sambangan tahun 20122016 sebesar -0,949.Besarnya koefisien korelasi tersebut menunjukkan bahwa adanya hubungan antara pertumbuhan penduduk dengan daya dukung lahan 
pertanian.Tanda negatif yang dihasilkan dari output SPSS menunjukan bahwa arah hubungan kedua variabel tersebut adalah negatif. Korelasi negatif menunjukkan arah yang berlawanan, artinya jika variabel pertumbuhan penduduk besar, maka variabel daya dukung lahan pertanian kecil.

c.

\section{Regresi Linier}

Untuk mengetahui besarnya dampak atau pengaruh dari pertumbuhan penduduk dengan daya dukung lahan pertanian digunakan analisis regresi linier.Dalam penelitian ini yang merupakan variabel bebas (independent) adalah pertumbuhan penduduk dan variabel terikat (dependent) adalah daya dukung lahan pertanian. Hasil analisis regresi linier dengan menggunakan SPSS 16.0 disajikan pada tabel 10 .

Tabel 10. Hasil Analisis Regresi Linier

\begin{tabular}{|c|c|c|c|c|c|c|}
\hline \multirow[b]{2}{*}{ Model } & & \multicolumn{2}{|c|}{ Unstandardized Coefficients } & \multirow{2}{*}{$\begin{array}{c}\text { Standardized } \\
\text { Coefficients } \\
\text { Beta } \\
\end{array}$} & \multirow[b]{2}{*}{1} & \multirow[b]{2}{*}{ Sig. } \\
\hline & & $B$ & Stod Error & & & \\
\hline 1 & (Constant) & 14.297 & .747 & & 19.146 & .000 \\
\hline & Pert_Penduduk & .2 .319 & .444 & .949 & .5 .224 & .014 \\
\hline
\end{tabular}

a. DependentVariable: DD_Lahan

Berdasarkan tabel 10 menunjukan nilai koefisien regresi linier(B), maka diperoleh persamaan regresi sebagai berikut.

$$
\begin{gathered}
Y=a+b X \\
\hat{Y}=14,297-2,319 X
\end{gathered}
$$

Hasil dari regresi di atas dapat diinterpretasikan sebagai berikut.

a. Nilai a merupakan angka konstanta dari kolom unstandardized coefficients yang memiliki nilai sebesar 14,297. Angka ini mempunyai arti jika variabel $X$ (Pertumbuhan penduduk) tidak mengalami perubahan atau konstan, maka variabel $Y$ (daya dukung lahan pertanian) mengalami peningkatan sebesar 14,297.

b. Nilai b merupakan angka koefisien regresi pertumbuhan penduduk yang memiliki nilai sebesar - 2,319. Angka ini memiliki arti bahwa setiap peningkatan $1 \%$ variabel $X$ maka variabel $Y$ akan mengalami penurunan sebesar 2,319. Tanda negative yang dihasilkan menunjukan bahwa variabel $X$ memiliki pengaruh negative terhadap variabel $\mathrm{Y}$.

Berdasarkan analisis yang dilakukan daya dukung lahan pertanian Desa Sambangan setiap tahun mengalami penurunan, sementara itu jumlah penduduk semakin meningkat. Nilai daya dukung lahan pertanian Desa Sambangan dari tahun 2012-2016 memenuhi standar evaluasi, yaitu $\alpha>1$. Hal ini menunjukan bahwa daya dukung lahan pertanian di Desa Sambangan mampu swasembada pangan dan mampu memberikan kehidupan yang layak bagi penduduknya. Walaupun jumlah penduduk meningkat dan daya dukung lahan pertanian berkurang, Desa Sambangan tetap mampu swasembada. $\mathrm{Hal}$ ini dikarenakan wilayah Desa sambangan memiliki luas pertanian yang cukup memadai dan masih mampu untuk memenuhi kebutuhan penduduk. Apabila terjadi pertumbuhan penduduk yang sangat tinggi setiap tahun, maka suatu wilayah tidak akan mampu untuk memenuhi kebutuhan penduduk. Hal ini disebabkan oleh daya dukung lahan semakin berkurang.

Berdasarkan hasil uji korelasi dan regresi linier dapat disimpulkan bahwa pertumbuhan penduduk memiliki pengaruh yang negatif terhadap daya dukung lahan pertanian di Desa Sambangan. Hasil analisis ini didukung oleh hasil penelitian Irsawan (2016) yang menyatakan bahwa pertumbuhan penduduk pada suatu wilayah akan memberikan dampak negatif terhadap perekonomian, tingkat kemiskinan, daya dukung lahan di suatu wilayah.

Pertumbuhan penduduk yang tinggi akan menimbulkan berbagai dampak di antaranya adalah meningkatkan kebutuhan lahan baik untuk pemukiman, sarana infrastruktur, dan lahan pertanian. Pada kenyataannya terjadi kecenderungan penyempitan lahan untuk pertanian sebagai imbas dari 
pembangunan fisik suatu daerah. Di sisi lain pertambahan penduduk yang terus meningkat akan memicu penurunan kapasitas daya dukung lahan pertanian. Hal ini juga didukung oleh penelitian Tiandi (2016) mengungkapkan bahwa meningkatnya pertumbuhan penduduk di suatu wilayah akan berdampak pada kebutuhan akan ruang salah satunya untuk permukiman. Selain itu, akibat meningkatnya laju pertambahan penduduk menyebabkan terjadinya alih fungsi lahan dari lahan pertanian ke pemukiman, pertokoan, dan infrastruktur lainnya (Syaifuddi, Hamrie, \& Dahlan, 2016).

Dalam mengantisipasi alih fungsi lahan agar tidak terjadi lagi ada beberapa poin penting yang perlu diperhatikan secara serius sebagai seruan kepada Pemerintah Desa Sambangan dalam konteks perlindungan lahan pertanian sebagai penghasil pangan utama. Pemerintah melakukan upaya perlindungan lahan pertanian produktif sebagai penghasil pangan maupun lahan pertanian pangan yang sudah ada agar fungsinya berkelanjutan.

\section{SIMPULAN DAN SARAN}

\section{Simpulan}

Berdasarkan hasil analisis data dan pembahasan, dapat disimpulkan halhal sebagai berikut.

1. Pertumbuhan penduduk Desa Sambangan mengalami peningkatan setiap tahun. Berdasarkan hasil analisis dengan menggunakan persamaan eksponensial diperoleh rata-rata laju pertumbuhan penduduk di Desa Sambangan sebesar 1,41\% per tahun dalam periode tahun 20122016.

2. Dalam periode tahun $2012-2016$, luas lahan pertanian mengalami penurunan akibat adanya alih fungsi lahan pertanian ke non pertanian. Nilai daya dukung lahan pertanian Desa Sambangan dari tahun 2012-2016 memenuhi standar evaluasi, yaitu $\alpha>1$. Hal ini menunjukan bahwa daya dukung lahan pertanian di Desa Sambangan masih mampu berswasembada pangan dan mampu memberikan kehidupan yang layak bagi penduduknya.

3. Laju pertumbuhan penduduk Desa Sambangan memiliki dampak negatif terhadap nilai daya dukung lahan pertanian di wilayah tersebut. Hasil uji korelasi pearson product moment diperoleh besar koefisien korelasi antara pertumbuhan penduduk dengan daya dukung lahan pertanian Desa Sambangan tahun 2012-2016 sebesar $-0,949$. Hasil uji regresi linier sederhana diperoleh persamaan $Y=14,297-2,319 X$.

\section{SARAN}

Berdasarkan hasil penelitian, dapat dikemukakan beberapa saran sebagai berikut.

1. Bagi pemerintah Desa Sambangan agar lebih memperhatikan rencana pembangunan yang akan datang, sehingga pembangunan yang dilakukan tidak banyak mengorbankan lahan pertanian yang masih produktif.

\section{DAFTAR PUSTAKA}

Ariani, R.D., \& Hariani, R. 2012. Tekanan Penduduk Terhadap Lahan Pertanian Di Kawasan Pertanian (Kasus Kecamatan Minggir Dan Moyudan). Jurnal Bumi Indonesia. 1(3): 30-45.

Astawa, Ida Bagus Made, Sarmita I Made. 2016. Geografi Penduduk. Buku Ajar (tidak diterbitkan). Singaraja:Undiksha.

Badan Pusat Statistik Provinsi Bali. 2017. Provinsi Bali dalam Angka.

$\begin{array}{ccc}\text { Badan Pusat } & \text { Statistik } & \text { Kabupaten } \\ \text { Buleleng. } & 2011 . & \text { Kecamatan } \\ \text { Sukasada dalam Angka. } & \end{array}$

Badan Pusat Statistik Kabupaten Buleleng. 2012. Kecamatan Sukasada dalam Angka.

Badan Pusat Statistik Kabupaten Buleleng. 2013. Kecamatan Sukasada dalam Angka. 
Badan Pusat Statistik Kabupaten Buleleng. $2014 . \quad K e c a m a t a n$ Sukasada dalam Angka.

Badan Pusat Statistik Kabupaten Buleleng. $2015 . \quad$ Kecamatan Sukasada dalam Angka.

Badan Pusat Statistik Kabupaten Buleleng. 2016. Kecamatan Sukasada dalam Angka.

BPS Negara Republik Indonesia. 2010. Indonesia Dalam Angka 2011.

Christian, C., Tedjo, P., \& Martono, B. 2016. Analisis dampak pertumbuhan penduduk terhadap kualitas hidup masyarakat provinsi jawa tengah. Jurnal IImiah UNTAG Semarang, 3(5): 48-63.

Irsawan, W. 2016. Pengaruh pertumbuhan penduduk terhadap konversi lahan pertanian di kecamatan colomadu tahun 2005-2015. Jurnal ASE, 7(2): 61-68.

Mantra, IB. 1986. Pengantar Studi Demografi. Yogyakarta: Nur Cahaya.

Suputra, D. A. (2012). "Faktor-faktor yang mempengaruhi alih fungsi lahan studi kasus di Subak Daksina, Desa Tibuneneng, Kecamatan Kuta Utara, Kabupaten Badung". E-journal Agribisnis dan Pariwisata.1(1): 6567.

Syaifuddin., Hamire, A., \& Dahlan. 2016. Hubungan antara jumlah penduduk dengan alih fungsi lahan di kecamatan somba opu kabupaten gowa. Jurnal Agrisistem, 9(2): 169179.

Tiandi, A. 2016. Pertumbuhan penduduk dan pola permukiman di kota cilegon tahun 2001-2015. Jurnal IImiah UNTAG Semarang, 7(3): 102-114. 